\section{ANALISA FAKTOR-FAKTOR YANG MEMPENGARUHI IMPLEMENTASI STANDAR AKUNTANSI "PEMERINTAHAN" BERBASIS AKRUAL PADA PEMERINTAH KOTA BANDUNG}

\section{ANALYSIS OF FACTORS AFFECTING THE IMPLEMENTATION OF ACCRUAL BASED GOVERNMENTAL STANDARDS IN BANDUNG CITY GOVERNMENT}

\author{
Tyas Ninditha Arih ${ }^{1}$, Sri Rahayu², Annisa Nurbaiti ${ }^{3}$ \\ Fakultas Ekonomi dan Bisnis, Universitas Telkom \\ 1yas.ninditha@gmail.com, ${ }^{2}$ srirahayu@telkomuniversity.ac.id, ${ }^{3}$ annisanurbaiti@, \\ telkomuniversity.ac.id
}

\begin{abstract}
Abstrak
Setelah dikeluarkannya PP No. 71 tahun 2010, pemerintah khususnya pemerintah daerah wajib menerapkan SAP berbasis akrual selambat-lambatnya 5 tahun, yaitu di tahun 2015 . Namun, hingga saat ini masih banyak instansi yang belum melaksanakan sepenuhnya. Ada berbagai faktor yang mempengaruhi kesiapan pemerintah dalam menerapkan SAP berbasis akrual. Tujuan penelitian ini adalah untuk mengetahui faktor-faktor yang mempengaruhi kesiapan pemerintah dalam implementasi SAP berbasis akrual ini antara lain Kualitas SDM, Perangkat Pendukung, dan Gaya Kepemimpinan khususnya pada Pemerintah Kota Bandung. Metode yang digunakan dalam penelitian ini adalah analisis regresi linier berganda dengan aplikasi statistik data SPSS 20.0. Populasi dalam penelitian ini adalah Satuan Kerja Perangkat Daerah (SKPD), penetapan sampel dengan menggunakan sampling sensus. Hasil penelitian menunjukan bahwa Kualitas SDM dan Perangkat Pendukung secara parsial berpengaruh signifikan dengan arah yang positif, sedangkan Gaya Kepemimpinan tidak berpengaruh terhadap Implementasi SAP Berbasis Akrual pada Pemerintah Kota Bandung. Namun, secara simultan Kualitas SDM, Perangkat Pendukung, dan Gaya Kepemimpinan berpengaruh signifikan terhadap Implementasi SAP Berbasis Akrual pada Pemerintah Kota Bandung.
\end{abstract}

Kata kunci: kualitas sumber daya manusia, perangkat pendukung, gaya kepemimpinan, implementasi standar akuntansi pemerintahan (SAP), basis akrual

\section{Abstract}

After the issuance of Government Regulation No. 71 of 2010, the Indonesian government especially local governments are required to implement Accrual Based Governmental Accounting Standards in the year of 2015. Nevertheless, some government institutions have not implemented the Accrual Based Governmental Accounting Standards fully. There are various factors affecting the government readiness in implementing the Accrual Based Governmental Accounting Standards. The purpose of this study was to determine how is the human resources quality, supporting devices, leadership style, and the implementation of Accrual Based Governmental Accounting Standards in Bandung City Government. This study also aimed to determine the affect of the human resources quality, supporting devices, and leadership style on the implementation of Accrual Based Governmental Accounting Standards in Bandung City Government, either simultaneously or partially. This study used a Multiple Linear Regression Analysis, and interpret output from the SPSS 20.00 software. Regional Working Units (SKPD) defined as a population and used census sampling technique. The results showed that the human resources quality and supporting devices, partially have a significant influence towards in a positive, while the leadership style has no affect on the implementation of Accrual Based Governmental Accounting Standards in Bandung City Government. However, simultaneously human resources quality, supporting devices, and leadership style have a significant influence on the implementation of Accrual Based Governmental Accounting Standards in Bandung City Government. The results could help to prepare and develop personnel in the finance department through socialization and intensive training, so that they have the competence as an executor to implement Accrual Based Governmental Accounting Standards.
JURNAL

MANAJEMEN

INDONESIA

Vol. 17 - No. 1

April 2017 
JURNAL

MANAJEMEN

INDONESIA

Vol. 17 - No. 1

April 2017
Keywords: human resources quality, supporting devices, leadership style, governmental accounting standards, accrual based

\section{Pendahuluan}

Regulasi terkait pengelolaan keuangan negara di Indonesia selalu memberikan perubahan dalam perbaikan peningkatkan kinerja pengelolaan keuangan negara yang dilakukan secara berkelanjutan. Upaya pemerintah untuk mencapai tata kelola pemerintahan yang baik dilakukan dengan cara meningkatkan transparansi dan akuntabilitas pengelolaan keuangan negara, salah satunya dengan melakukan pengembangan kebijakan akuntansi pemerintah berupa standar akuntansi pemerintah (SAP) (Ardiansyah, 2013). Hal ini disebut sebagai reformasi keuangan negara dengan dikeluarkannya tiga Undang-Undang (UU), yakni UU No. 17 Tahun 2003 tentang Keuangan Negara, UU No. 1 Tahun 2004 tentang Perbendaharaan Negara, dan UU No. 15 Tahun 2004 tentang Pemeriksaan Pengelolaan dan Tanggung Jawab Keuangan Negara. Salah satu dari UU tersebut, yakni tercantum dalam pasal 3 ayat (1) UU No. 17 Tahun 2003 menyatakan bahwa Keuangan Negara dikelola secara tertib, taat pada peraturan perundang-undangan, efisien, ekonomis, efektif, transparan, dan bertanggung jawab dengan memperhatikan rasa keadilan dan kepatutan. Sehingga dalam rangka mewujudkan pasal tersebut, salah satunya dengan melakukan penerapan SAP berbasis akrual yang dituangkan dalam Peraturan Pemerintah (PP) No. 71 tahun 2010 tentang penerapan akuntansi berbasis akrual untuk menggantikan PP No. 24 tahun 2005 tentang penerapan akuntansi berbasis kas menuju akrual pada sektor pemerintahan.

Dalam UU No. 17 Tahun 2003 pasal 36 ayat (1) dinyatakan bahwa mengenai pengakuan dan pengukuran pendapatan dan belanja berbasis akrual harus dilaksanakan selambat-lambatnya dalam 5 (lima) tahun setelah diterbitkannya UU tersebut. Namun karena pemerintah belum mengeluarkan peraturan yang pasti dan khusus mengenai SAP berbasis akrual, dan diperkuat pula oleh penjelasan pada pasal yang sama dalam UU No. 17 Tahun 2003, menyatakan bahwa selama pengakuan dan pengukuran pendapatan dan belanja berbasis akrual belum dilaksanakan maka digunakan pengakuan dan pengukuran berbasis kas. Sehingga sebagai pedoman pelaksanaan SAP dikeluarkanlah PP No. 24 tahun 2005 tentang penerapan akuntansi berbasis kas menuju akrual. Kemudian sejak dikeluarkannya PP No. 71 Tahun 2010, maka SAP berbasis akrual telah memiliki landasan hukum sendiri untuk menerapkannya. Oleh karena itu pemerintah berkewajiban untuk melaksanakan regulasi tersebut, yakni dengan tidak lagi menggunakan basis kas dalam menerapkan SAP, tetapi mulai menggunakan basis akrual selambat-lambatnya 5 (lima) tahun sejak dikeluarkannya PP tersebut. Sehingga pada tahun 2015 seluruh sektor pemerintahan harus sudah menerapkan basis akrual secara penuh (full accrual). Seperti yang dinyatakan dalam UU No. 17 Tahun 2003 pasal 32 ayat (1) bahwa bentuk dan isi laporan pertanggungjawaban pelaksanaan APBN/APBD disusun dan disajikan sesuai dengan SAP. Maka dalam hal ini adalah penerapan SAP berbasis akrual sebagaimana tercantum dalam PP No. 71 Tahun 2010 pasal 4 ayat (1). Dengan adanya perubahan SAP basis kas menuju basis akrual, maka akan membawa dampak bagi pengelolaan keuangan negara (Putra dan Ariyanto, 2015).

Penyusunan SAP sebagaimana tertuang dalam UU No. 17 Tahun 2003 Pasal 32 ayat (2) bahwa SAP sebagaimana dimaksud dalam pasal 32 ayat (1) disusun oleh suatu komite standar yang independen, yaitu Komite Standar Akuntansi Pemerintah (KSAP) dan ditetapkan dengan PP setelah terlebih dahulu mendapat pertimbangan dari Badan Pemeriksa Keuangan (BPK).

Beberapa negara telah menerapkan akuntansi pemerintahan berbasis akrual seperti Malaysia, Estonia, dan Selandia Baru. Salah satu negara yang paling sukses menerapkan akuntansi berbasis akrual pada sektor publiknya, yaitu Selandia Baru karena tingkat perubahan dalam manajemen sektor publik yang cepat dan inovatif. Lain halnya dengan Selandia Baru, di Negara Malaysia masih terdapat kendala dalam penerapan akuntansi berbasis akrual, yakni dalam hal keterbatasan tenaga akuntan yang berkualitas dan profesional (Saleh and Pendlebury, 2006; dalam Putra dan Ariyanto, 2015). Sedangkan di Negara Estonia telah terdapat kualifikasi untuk tenaga kerja akuntan (Tikk, 2010; 
Walaupun full accrual baru saja diimplementasikan pada tahun 2015 pada setiap instansi pemerintahan, namun adanya perubahan terkait SAP dari basis kas menuju akrual menjadi basis akrual dilakukan karena basis akrual memiliki kelebihan yang tidak terdapat dalam basis sebelumnya. Kelebihan-kelebihan tersebut dapat membuat pengelolaan serta penyajian laporan keuangan yang lebih baik, sehingga dapat meningkatkan kinerja pemerintahan. Hal ini dapat dilihat dari adanya pengakuan pendapatan pada basis akrual, yang artinya bahwa pendapatan diakui pada saat timbulnya hak atas pendapatan tersebut atau adanya aliran masuk sumber daya ekonomi. Oleh karena itu, dengan adanya pengakuan pendapatan maka akan terjadi peningkatan pendapatan karena kas yang belum diterima dapat diakui sebagai pendapatan. Hal ini tidak berlaku pada basis kas menuju akrual yang hanya mencatat sebagai kas pada saat kas tersebut diterima, sehingga tidak akan menyulitkan dalam pencatatan karena tidak diakui pendapatannya. Selain itu, jika dalam basis kas menuju akrual penyajikan Laporan Operasional dan Laporan Perubahan Ekuitas bersifat optional, namun dalam basis akrual kedua pelaporan tersebut diwajibkan. Oleh karena itu, dengan ada kewajiban untuk menyajikan kedua laporan tersebut, maka dapat dijadikan pengukuran/pembanding antara tahun yang berjalan dengan tahun sebelumnya mengenai perubahan dari pendapatan, beban, dan ekuitas instansi. Dengan adanya pengukuran/pembanding tersebut, maka dapat dijadikan saransaran untuk instansi agar dapat lebih meningkatkan kinerja untuk mencapai tujuan yang lebih baik dengan memperbaiki hal-hal yang masih kurang serta meningkatkan apa yang telah dicapai dengan baik menjadi lebih baik lagi.

Penerapan sistem akuntansi berbasis akrual merupakan proses yang berkesinambungan serta terpadu, dan dampak yang dihasilkan dalam penerapan sistem ini pun tidak dapat dilihat dalam waktu singkat, sehingga pemahaman tentang faktorfaktor yang mempengaruhi keberhasilan atau kegagalan dalam pengenalan sistem akuntansi yang baru, khususnya pada konteks pemerintahan adalah penting (Fuad, 2013). Menurutnya tingkat penerapan akuntasi akrual pada pemerintah untuk tingkat satuan kerja hanya sampai pada level tertentu, yaitu 33,3\%, atau dengan kata lain masih sangat rendah. Oleh karena itu diperlukan penelitian lebih lanjut mengenai analisis faktor-faktor yang dapat mempengaruhi penerapan SAP berbasis akrual. Dari beberapa sumber penelitian sebelumnya diperoleh informasi bahwa kualitas sumber daya manusia (SDM), perangkat pendukung, dan gaya kepemimpinan merupakan faktor yang banyak disebut peneliti telah mempengaruhi penerapan SAP berbasis akrual.

Penelitian yang dilakukan oleh Kristyono et al (2013), Ardiansyah (2013), Nufus (2014), Negara (2015), Putra dan Ariyanto (2015), Sukadana dan Mimba (2015) menyatakan bahwa kualitas SDM berpengaruh positif terhadap kesiapan dan keberhasilan penerapan SAP berbasis akrual, dengan tingkat yang masih rendah. Hal ini diperkuat dengan hasil penelitian Sudaryati dan Heriningsih (2014) yang menyatakan bahwa kompetensi SDM berpengaruh signifikan terhadap keberhasilan penerapan akuntansi akrual (PP No.71 Tahun 2010). Fuad (2015) yang melakukan penelitian di Wilayah Kerja KPPN Semarang I juga menyatakan bahwa SDM yang ada, dalam hal ini pelatihan yang diberikan kepada staf keuangan terkait penerapan akuntansi akrual terbukti berpengaruh secara positif dan signifikan terhadap tingkat penerapan akuntansi akrual. Tetapi hal ini berbanding terbalik dengan tingkat pendidikan staf keuangan yang tidak berpengaruh secara signifikan terhadap tingkat penerapan akuntansi akrual. Beberapa penelitian sebelumnya menyatakan bahwa SDM menjadi faktor utama dalam membentuk keberhasilan penerapan SAP berbasis akrual. Namun ternyata dalam praktiknya, SDM yang memadai masih dikatakan rendah. Padahal regulasi terkait SAP berbasis akrual telah ditetapkan dan diwajibkan bagi seluruh sektor pemerintahan. Terlebih dengan diterapkannya SAP berbasis akrual juga menilai kinerja dari pemerintah daerah, bukan hanya mengenai pelaporan keuangan saja.

Pada beberapa penelitian sebelumnya juga menyatakan bahwa perangkat pendukung yang ada pada sektor pemerintahan masih rendah, padahal memiliki peranan penting dalam menunjang kegiatan. Kristyono dkk (2013) menyatakan bahwa faktor perangkat pendukung berpengaruh terhadap keberhasilan pengelolaan keuangan daerah berdasarkan SAP. Berdasarkan penelitian tersebut, adanya peningkatan perangkat 
JURNAL

MANAJEMEN

INDONESIA

Vol. 17 - No. 1

April 2017 pendukung (hardware dan software) yang memadai secara parsial dan simultan dapat meningkatkan keberhasilan pengelolaan keuangan daerah (Pemerintah Kota Semarang) lebih khusus pada Dinas Pendidikan Kota Semarang. Namun penelitian yang dilakukan oleh Fuad (2013) menyatakan bahwa perangkat pendukung, dalam hal ini kualitas TI tidak berpengaruh secara signifikan. Arif (2013) menyatakan bahwa dalam hal sarana dan prasarana serta sistem informasi telah dilakukan beberapa persiapan untuk mendukung pelaksanaan. Berdasarkan fenomena yang terjadi, ternyata dalam praktiknya masih terdapat Satuan Kerja Perangkat Daerah (SKPD) yang menggunakan perangkat ilegal. Penggunaan ilegal rentan terhadap malware dan penyusupan, juga rentan rusak Hal ini akan menyebabkan tercurinya data-data penting dan peretasan oleh hacker yang berdampak pada kerusakan komputer.

Simanjuntak (2010) menyatakan bahwa dukungan yang kuat dari pimpinan dan kerjasama dengan pegawai merupakan kunci keberhasilan dari suatu perubahan. Putra dan Ariyanto (2015) menyatakan bahwa terdapat pengaruh positif gaya kepemimpinan terhadap kesiapan penerapan SAP berbasis akrual. Sedangkan penelitian sejenis yang dilakukan oleh Mehrolhassani et al (2015) menyatakan bahwa faktor kepemimpinan masih sangat rendah dalam implementasi akuntansi berbasis akrual pada sektor kesehatan. Kesadaran dan komitmen terhadap pelaksanaan sistem akuntansi akrual di unit mereka rendah dan tidak memiliki kerja sama dalam memperoleh laporan akrual sistem, serta tidak ada dukungan untuk pelaksanaan perubahan. Berdasarkan penelitian sebelumnya menyatakan bahwa seorang pemimpin harus memahami para pegawainya. Namun sampai saat ini masih ada pemimpin yang belum dapat menerapkan itu semua.

\section{Kajian Teoretis}

\subsection{Kualitas Sumber Daya Manusia (SDM)}

Menurut Azhar (2007) dalam Kristyono et al (2013), SDM adalah kesatuan tenaga manusia dalam suatu organisasi dan untuk mencapai tujuan organisasi, yang meliputi latar belakang pendidikan yang diperoleh responden, pemahaman tentang tugasnya, kesiapan dalam melakukan perubahan dalam proses penyusunan laporan keuangan. Goetsch dan Davis dalam Tjiptono (2011:164) menjelaskan bahwa kualitas merupakan kondisi dinamis yang berhubungan dengan produk, jasa, SDM, proses, dan lingkungan yang memenuhi atau melebihi harapan. Hal ini berarti bahwa kualitas SDM merupakan kondisi yang dimiliki seseorang yang melebihi harapan. Tjiptoherijanto (2001) dalam Nurillah (2014) menyatakan untuk menilai kualitas SDM dalam melaksanakan suatu fungsi, termasuk akuntansi, dapat dilihat dari level of responsibility/tingkat tanggung jawab dan kompetensi SDM tersebut, dimana level of responsibility/tingkat tanggung jawab dapat dilihat dari integritas, pelaksanaan dan penyelesaian tugas, serta adaptasi terhadap perubahan. Sedangkan kompetensi dapat dilihat dari pengetahuan, kemampuan, dan pelatihan yang diikuti oleh SDM.

Semakin baik kualitas SDM dan ketersediannya dalam sektor pemerintahan, maka implementasi SAP berbasis akrual akan semakin baik. Oleh karena itu kualitas SDM berpengaruh positif terhadap implementasi SAP berbasis akrual. Hipotesis yang dibangun untuk kualitas SDM terhadap implementasi SAP berbasis akrual ini adalah:

$\mathrm{H}_{1}$ : Kualitas Sumber Daya Manusia secara parsial berpengaruh positif terhadap Implementasi Standar Akuntansi Pemerintahan Berbasis Akrual

\subsection{Perangkat Pendukung}

Perangkat pendukung adalah ketersediaan perangkat yang membantu SDM dalam melaksanakan tugas seperti tersedianya komputer dan software yang berkaitan dengan kebutuhan dalam membantu penyusunan laporan keuangan pemerintah daerah (Sudaryati dan Heriningsih, 2014). Berdasarkan penelitian yang dilakukan oleh Sulani (2009) dalam mengukur perangkat pendukung, terdiri dari indikator Ketersediaan Perangkat Keras/Hardware dan Ketersediaan Perangkat Lunak/Software. Indikator Ketersediaan Perangkat Keras/Hardware dapat dilihat dari ada tidaknya fasilitas komputer dan perangkat keras pendukung lainnya yang sesuai dengan spesifikasi, 
fasilitas komputer dan perangkat keras pendukung lainnya yang digunakan adalah legal/ asli (tidak bajakan), dan adanya penanganan tepat waktu terhadap perangkat yang rusak. Sedangkan Ketersediaan Perangkat Lunak/Software dapat dilihat dari adanya SOP (Standar Operasional Prosedur) pengelolaan keuangan berbasis akrual dan diacu secara konsisten, adanya perangkat lunak atau aplikasi akuntansi berbasis akrual yang sesuai dengan spesifikasi yang dibutuhkan, perangkat lunak yang digunakan adalah legal/asli (tidak bajakan), serta adanya sistem keamanan antivirus yang selalu di update.

Semakin memadai seluruh indikator perangkat pendukung pada sektor pemerintahan, maka implementasi SAP berbasis akrual akan semakin baik. Dengan demikian, dapat dikatakan bahwa perangkat pendukung berpengaruh positif terhadap implementasi SAP berbasis akrual. Hipotesis yang dibangun untuk perangkat pendukung terhadap implementasi SAP berbasis akrual ini adalah:

$\mathrm{H}_{2}$ : Perangkat Pendukung secara parsial berpengaruh positif terhadap Implementasi Standar Akuntansi Pemerintahan Berbasis Akrual

\subsection{Perangkat Pendukung}

Danim (2010:6) menjelaskan bahwa kepemimpinan adalah setiap tindakan yang dilakukan individu atau kelompok untuk mengkoordinasikan dan memberi arah kepada individu atau kelompok lain yang tergabung dalam wadah tertentu untuk mencapai tujuan-tujuan yang telah ditetapkan sebelumnya. Berdasarkan Teori Kurt Lewin mengenai jenis-jenis gaya kepemimpinan dalam Danim (2010:7), maka gaya kepemimpinan dapat diukur dengan pemberian tanggung jawab secara jelas dan rinci, bersikap tegas kepada para anggota terkait tugas yang dikerjakan, mendukung keputusan anggota yang dianggap tepat, anggota berani untuk tidak menerima keputusan pemimpin dan menegur tindakan yang kurang tepat, pemimpin melakukan diskusi partisipatif dengan anggota, serta pemberian wewenang dan kepercayaan kepada anggota.

Semakin baik/sesuai gaya kepemimpinan dalam sektor pemerintahan, maka implementasi SAP berbasis akrual akan semakin baik. Hal ini disebabkan karena gaya kepemimpinan yang baik tentunya akan membawa dampak kenyamanan dan kemudahan bagi para pegawai dalam melakukan pekerjaannya sehingga akan membawa dampak optimalisasi pencapaian tujuan organisasi, efektivitas, serta efisiensi dalam lingkup SAP berbasis akrual. Oleh karena itu gaya kepemimpinan berpengaruh positif terhadap implementasi SAP berbasis akrual. Hipotesis yang dibangun untuk gaya kepemimpinan terhadap implementasi SAP berbasis akrual ini adalah:

$\mathrm{H}_{3}$ : Gaya Kepemimpinan secara parsial berpengaruh positif terhadap Implementasi Standar Akuntansi Pemerintahan Berbasis Akrual

\subsection{Implementasi Standar Akuntansi Pemerintahan Berbasis Akrual}

Berdasarkan PP No. 71 Tahun 2010, SAP berbasis akrual adalah SAP yang mengakui pendapatan, beban, aset, utang, dan ekuitas dalam pelaporan finansial berbasis akrual, serta mengakui pendapatan, belanja, dan pembiayaan dalam pelaporan pelaksanaan anggaran berdasarkan basis yang ditetapkan dalam APBN/APBD.

Berdasarkan PP No. 71 Tahun 2010, SAP berbasis akrual adalah SAP yang mengakui pendapatan, beban, aset, utang, dan ekuitas dalam pelaporan finansial berbasis akrual, serta mengakui pendapatan, belanja, dan pembiayaan dalam pelaporan pelaksanaan anggaran berdasarkan basis yang ditetapkan dalam APBN/APBD.

Penelitian Fuad (2013) dan Simanjuntak (2010) menyatakan bahwa implementasi SAP berbasis akrual dapat diukur dengan telah adanya penerapan SAP berbasis akrual secara penuh sesuai dengan PP No. 71 Tahun 2010; peningkatan pendapatan; dan kesulitan penerapan SAP berbasis akrual. Sedangkan menurut Study No. 14 yang diterbitkan oleh International Public-Sector Accounting Standards Board (2011), indikator implementasi SAP berbasis akrual adalah menilai akuntabilitas untuk pengelolaan seluruh sumber daya entitas serta penyebaran sumber daya tersebut; menilai kinerja, posisi keuangan, dan arus kas dari suatu entitas; serta pengambilan keputusan mengenai penyediaan
JURNAL

MANAJEMEN

INDONESIA

Vol. 17 - No. 1

April 2017 


\section{JURNAL}

MANAJEMEN

INDONESIA

Vol. 17 - No. 1

April 2017

\section{Gambar 1.}

Kerangka Pemikiran sumber daya atau melakukan bisnis dengan suatu entitas.

Berdasarkan teori dan penjelasan tersebut, dapat diidentifikasi tiga variabel independen yaitu Kualitas SDM $\left(X_{1}\right)$, Perangkat Pendukung $\left(X_{2}\right)$, dan Gaya Kepemimpinan $\left(\mathrm{X}_{3}\right)$ yang diperkirakan akan mempengaruhi Implementasi SAP Berbasis Akrual (Y) baik secara simultan maupun parsial. Secara ringkas model kerangka pemikiran dapat dilihat pada gambar berikut.

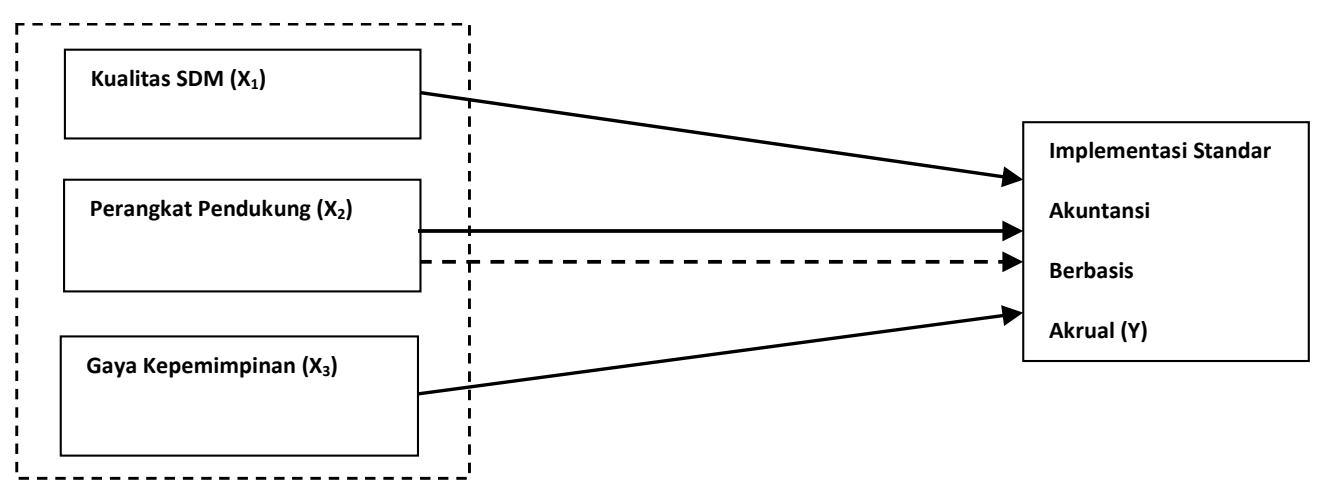

\section{Metode Penelitian}

Populasi dalam penelitian ini adalah seluruh Satuan Kerja Perangkat Daerah (SKPD) berupa dinas dan badan di Kota Bandung sebanyak 23 SKPD. Teknik sampel yang digunakan dalam penelitian ini adalah census sampling dengan kriteria diantaranya adalah seluruh Kepala Sub Bagian Keuangan beserta seluruh pegawai/staf bagian keuangan pada setiap SKPD berupa dinas dan badan di Kota Bandung yang menjalankan tugas terkait dengan penerapan sistem akuntansi berbasis akrual secara langsung.

Berdasarkan kriteria di atas maka diperoleh 138 orang yang menjadi responden dalam penelitian ini. Teknik analisis yang digunakan dalam penelitian ini menggunakan analisis statistik deskriptif dan regresi linier berganda. Sebelum melakukan analisis statistik deskriptif, langkah pertama yang harus dilakukan adalah melakukan uji validitas dan reliabilitas atas seluruh pernyataan yang ada di dalam kuesioner untuk mengetahui apakah pernyataan yang digunakan telah valid dan reliabel untuk diuji. Hasil pengujian didapat bahwa seluruh pernyataan dalam kuesioner pada penelitian ini telah valid dan reliabel (layak). Setelah itu, barulah dilakukan analisis statistik deskriptif. Kemudian dilakukan uji asumsi klasik yang terdiri dari uji normalitas, multikolonieritas, dan heteroskedastisitas, serta dilakukan uji hipotesis dengan menggunakan analisis regresi linier berganda, yaitu untuk uji t dan uji F.

\section{Hasil dan Pembahasan}

Hasil statistik deskriptif setiap variabel operasional disajikan pada tabel berikut ini. Dari data tersebut dapat dilihat bahwa variabel Kualitas SDM, Perangkat Pendukung, Gaya Kepemimpinan, dan Implementasi SAP Berbasis Akrual rata-rata mayoritas responden memilih setuju, artinya setiap pernyataan yang ada dalam kuesioner sesuai dengan yang terjadi di lapangan. Hal ini mengindikasikan bahwa Kualitas SDM, Perangkat Pendukung, Gaya Kepemimpinan, dan Implementasi SAP Berbasis Akrual yang sebenarnya dimiliki oleh Pemerintah Kota Bandung telah berada dalam kategori tinggi atau baik. Sumber: Output SPSS 20.0 (data yang telah diolah)

\begin{tabular}{|l|l|l|l|l|l|l|}
\hline Rata-rata & SS & S & R & TS & STS & Persentase Skor \\
\hline Variabel & 12 & 88 & 23 & 13 & 2 & $73,94 \%$ \\
\hline Kualitas SDM & 18 & 98 & 16 & 6 & 0 & $78,38 \%$ \\
\hline Perangkat Pendukung & 12 & 109 & 14 & 3 & 0 & $78,65 \%$ \\
\hline Gaya Kepemimpinan & 18 & 98 & 21 & 1 & 0 & $79,42 \%$ \\
\hline Implementasi SAP Berbasis Akrual &
\end{tabular}

\section{Hasil Statistik}

Deskriptif

Sumber: Output SPSS 20.0 (data yang telah diolah) 
Persentase skor Kualitas SDM menunjukan angka sebesar 73,94\%. Dengan demikian Kualitas SDM berada pada kategori Tinggi, sehingga peluang pelaksanaan kegiatan dan tercapainya tujuan, sasaran organisasi, serta pelaksanaan perubahan-perubahan akan semakin besar dan baik karena SDM merupakan kunci utama dalam keberhasilan itu semua. Hal ini dapat dilihat berdasarkan hasil indikator Tingkat Tanggung Jawab SDM yang tinggi. Nilai tersebut diperoleh dari adanya integritas tenaga keuangan yang tinggi dan mampu beradaptasi serta merasa nyaman dengan adanya perubahan penggunaan standar akuntansi pemerintahan dari basis kas menuju akrual menjadi berbasis akrual. Selain itu, indikator Kompetensi SDM yang dimiliki oleh pegawai bagian keuangan juga tinggi. Nilai tersebut diperoleh dari adanya kesesuaian latar belakang/jurusan pendidikan yang dibutuhkan dalam pekerjaan, yakni ekonomi/akuntansi; memiliki pengetahuan tentang akuntansi pemerintahan berbasis akrual; memiliki keterampilan dalam mengoperasikan hardware dan software akuntansi pemerintahan yang dapat mendukung target pencapaian hasil maksimal; memiliki pengalaman di bidang pengelolaan keuangan pada lingkungan pemerintah yang sesuai dan mendukung tugas saat ini; memiliki kemampuan berbagi keterampilan mengoperasikan hardware dan software serta berbagi pengetahuan terkait pelaksanaan basis akrual pada tenaga keuangan lain; dan pegawai keuangan telah memahami sepenuhnya mengenai isi PP No. 71 Tahun 2010.

Persentase skor Perangkat Pendukung menunjukan angka sebesar 78,38\%. Dengan demikian Perangkat Pendukung berada pada kategori Tinggi atau dengan kata lain perangkat pendukung yang terdapat di setiap instansi telah memadai. Hal ini dapat dilihat berdasarkan hasil indikator Ketersediaan Perangkat Keras/Hardware yang tinggi atau memadai. Nilai tersebut diperoleh dari adanya kesesuaian fasilitas komputer dan perangkat keras pendukung lainnya dengan spesifikasi yang dibutuhkan serta perangkat keras yang digunakan dalam instansi legal atau tidak bajakan untuk mendukung pelaksanaan tugas. Selain itu, indikator Ketersediaan Perangkat Lunak/ Software yang dimiliki oleh pegawai bagian keuangan juga tinggi atau memadai. Nilai tersebut diperoleh dari adanya kesesuaian software akuntansi berbasis akrual dengan spesifikasi yang dibutuhkan, perangkat lunak yang digunakan legal atau tidak bajakan, serta terdapat pengendalian terhadap sistem keamanan antivirus yang selalu di-update setiap waktu untuk mencegah terjadinya kerusakan atau kehilangan data keuangan.

Persentase skor Gaya Kepemimpinan menunjukan angka sebesar 78,65\%. Dengan demikian Gaya Kepemimpinan berada pada kategori Baik. Hal tersebut dapat dilihat dari mayoritas responden menjawab setuju untuk indikator pemberian tanggung jawab oleh pimpinan yang dilakukan secara jelas dan rinci, sehingga mudah dimengerti staf dalam pelaksanaan tugas; adanya ketegasan dari pimpinan kepada staf terkait tugas yang dikerjakan; pimpinan juga tidak keberatan untuk mendukung keputusan staf yang dianggap tepat dalam pekerjaan untuk mendukung pencapaian hasil yang optima; selain itu, staf juga memiliki keberanian untuk tidak menerima keputusan dan tindakan dari pimpinan yang dianggap kurang tepat dalam rangka pencapaian tujuan instansi. Hal lain dapat dilihat dari pelaksanaan diskusi partisipatif oleh pimpinan dengan melibatkan staf untuk memberikan saran dalam rangka mendapatkan keputusan dalam menyelesaikan masalah serta pimpinan juga menaruh kepercayaan dan memberikan wewenang pada staf dalam menyelesaikan tugasnya masing-masing.

Persentase skor Implementasi SAP Berbasis Akrual menunjukan angka sebesar $79,42 \%$. Dengan demikian Implementasi SAP Berbasis Akrual berada pada kategori Baik. Hal ini dapat dilihat dari mayoritas responden menjawab setuju untuk indikator penerapan SAP berbasis akrual secara penuh sesuai dengan PP No. 71 Tahun 2010; selain itu terdapat peningkatan akuntabilitas keuangan pada basis akrual untuk pengelolaan sumber daya entitas serta penyebaran sumber daya dibandingkan basis kas. Adapula peningkatan penilaian kinerja, posisi keuangan, dan arus kas instansi pada basis akrual serta terdapat peningkatan ketepatan pengambilan keputusan mengenai penyediaan sumber daya pada basis akrual dibandingkan basis kas.

Berdasarkan hasil uji normalitas, diperoleh nilai Asymp. Sig sebesar 0,284 lebih besar dari maximum error, yaitu $0,05(0,284>0,05)$, sehingga data tersebut dapat digunakan karena variabel residual berdistribusi normal. Selanjutnya dilakukan uji multikolieritas dan dapat disimpulkan bahwa tidak terdapat multikolonieritas karena nilai tolerance
JURNAL

MANAJEMEN

INDONESIA

Vol. 17 - No. 1

April 2017 


\section{JURNAL}

MANAJEMEN

INDONESIA

Vol. 17 - No. 1

April 2017

Table 2.

Hasil Pengujian

Analisis Regresi Linier

Berganda

Sumber:

Output SPSS 20.0 (data yang telah diolah)

Tabel 3.

Hasil Uji F

Sumber: Output SPSS 20.0 (data yang telah diolah) yang sudah lebih besar dari 0,1 dan nilai VIF yang kurang dari 10. Dengan demikian tidak terdapat hubungan yang kuat atau tidak berkaitan antarvariabel bebas yaitu Kualitas SDM, Perangkat Pendukung, dan Gaya Kepemimpinan. Hasil uji heteroskedastisitas dapat disimpulkan bahwa dalam model tidak terdapat heterokedastisitas karena pada gambar tidak ada pola yang jelas, serta titik-titik menyebar di atas dan di bawah angka 0 pada sumbu Y. Hal ini menandakan bahwa dalam model, variansi dari residual satu pengamatan ke pengamatan yang lain sama atau konstan. Sehingga asumsi tidak adanya heteroskedastisitas atau adanya homoskedastisitas sudah terpenuhi untuk persamaan regresi. Dengan demikian estimator model yang diperoleh akan memberikan hasil yang best atau dapat dikatakan varians dari residual adalah minimum. Untuk hasil pengujian analisis regresi linier berganda dalam penelitian ini disajikan pada tabel berikut.

\section{Coefficients $^{\mathrm{a}}$}

\begin{tabular}{|c|c|c|c|c|c|c|}
\hline \multicolumn{2}{|c|}{ Model } & \multicolumn{2}{|c|}{$\begin{array}{c}\text { Unstandardized } \\
\text { Coefficients }\end{array}$} & $\begin{array}{c}\text { Standardized } \\
\text { Coefficients }\end{array}$ & \multirow{2}{*}{$\mathrm{t}$} & \multirow{2}{*}{ Sig. } \\
\cline { 3 - 5 } & $\mathrm{B}$ & Std. Error & Beta & & \\
\hline \multirow{4}{*}{1} & (Constant) & $\mathbf{- . 4 2 4}$ & .356 & & -1.191 & .236 \\
\cline { 2 - 6 } & $\mathrm{X} 1$ & $\mathbf{. 5 9 0}$ & .092 & .473 & 6.420 & $\mathbf{. 0 0 0}$ \\
\cline { 2 - 6 } & $\mathrm{X} 2$ & $\mathbf{. 2 0 1}$ & .078 & .214 & 2.593 & $\mathbf{. 0 1 1}$ \\
\cline { 2 - 6 } & $\mathrm{X} 3$ & $\mathbf{. 1 5 7}$ & .087 & .135 & 1.816 & $\mathbf{. 0 7 2}$ \\
\hline
\end{tabular}

a. Dependent Variable: Skor Hasil Kuesioner Implementasi SAP Berbasis Akrual (Y)

Berdasarkan tabel 2 dapat diketahui nilai konstanta koefisien sehingga dapat dibentuk persamaan sebagai berikut:

$$
Y=-\mathbf{0 , 4 2 4}+\mathbf{0 , 5 9} X_{1}+\mathbf{0 , 2 0 1} X_{2}+\mathbf{0 , 1 5 7} X_{3}(1)
$$

Berdasarkan hasil koefisien determinasi diperoleh nilai $\mathrm{R}^{2}$ ( $\mathrm{R}$ square) sebesar 42,78\%. Hal ini mengindikasikan bahwa Kualitas SDM, Perangkat Pendukung, dan Gaya Kepemimpinan memberikan pengaruh secara simultan sebesar 42,78\% terhadap Implementasi SAP Berbasis Akrual. Sedangkan sisanya sebesar 57,22\% merupakan kontribusi faktor lain selain Kualitas SDM, Perangkat Pendukung, dan Gaya Kepemimpinan yang tidak diamati di dalam penelitian ini.

ANOVA $^{\mathrm{a}}$

\begin{tabular}{|c|c|c|c|c|c|c|}
\hline \multicolumn{2}{|c|}{ Model } & Sum of Squares & df & Mean Square & F & Sig. \\
\hline \multirow{3}{*}{1} & Regression & 20.140 & 3 & 6.713 & 33.334 & $\mathbf{. 0 0 0}^{\mathbf{b}}$ \\
\cline { 2 - 7 } & Residual & 26.987 & 134 & .201 & & \\
\cline { 2 - 7 } & Total & 47.128 & 137 & & & \\
\hline
\end{tabular}

a. Dependent Variable: Skor Hasil Kuesioner Implementasi SAP Berbasis Akrual (Y)

b. Predictors: (Constant), Skor Hasil Kuesioner Gaya Kepemimpinan (X3), Skor Hasil Kuesioner Kualitas Sumber Daya Manusia (X1), Skor Hasil Kuesioner Perangkat Pendukung (X2)

Berdasarkan hasil pengujian pada tabel 3 diperoleh nilai signifikansi yaitu $0,000<$ 0,05 sehingga Ho ditolak yang berarti secara simultan variabel Kualitas SDM, Perangkat Pendukung, dan Gaya Kepemimpinan berpengaruh signifikan terhadap Implementasi SAP Berbasis Akrual pada Pemerintah Kota Bandung.

\subsection{Pengaruh Kualitas Sumber Daya Manusia terhadap Implementasi Standar Akuntansi Pemerintahan Berbasis Akrual pada Pemerintah Kota Bandung}

Berdasarkan hasil pengujian secara parsial seperti yang ditunjukkan pada tabel 2 diperoleh nilai signifikansi Kualitas SDM yaitu $0,000<0,05$ sehingga Ho ditolak yang berarti secara parsial variabel Kualitas SDM berpengaruh signifikan dengan arah yang positif terhadap Implementasi SAP Berbasis Akrual pada Pemerintah Kota Bandung, artinya semakin tinggi kualitas SDM, maka implementasi SAP berbasis akrual pada Pemerintah Kota Bandung akan semakin baik. Hal ini ditunjang pula oleh penjelasan dari hasil pengujian statistik deskriptif dimana rata-rata mayoritas responden sebesar 88 
orang memilih setuju dengan skor rata-rata persentase mengenai tanggapan responden tentang Kualitas SDM sebesar 73,94\%, yang berarti Kualitas SDM pegawai bagian keuangan pada Satuan Kerja Perangkat Daerah (SKPD) Kota Bandung sudah tinggi. Sedangkan pada skor rata-rata persentase mengenai tanggapan responden tentang Implementasi SAP Berbasis Akrual pada Pemerintah Kota Bandung sebesar 79,42\% dengan rata-rata mayoritas responden sebesar 98 orang memilih setuju, yang berarti tingkat Implementasi SAP Berbasis Akrual pada Pemerintah Kota Bandung sudah baik. Hasil penelitian ini sejalan dengan penelitian Fuad (2013), Ardiansyah (2013), Kristyono et al (2013), Sudayarti dan Heriningsih (2014), Nufus (2014), Putra dan Ariyanto (2015), Sukadana dan Mimba (2015), serta Negara (2015) yang menyatakan bahwa Kualitas SDM berpengaruh positif terhadap implementasi SAP berbasis akrual.

\subsection{Pengaruh Perangkat Pendukung terhadap Implementasi Standar Akuntansi Pemerintahan Berbasis Akrual pada Pemerintah Kota Bandung}

Berdasarkan hasil pengujian secara parsial seperti yang ditunjukkan pada tabel 2 diperoleh nilai signifikansi Perangkat Pendukung yaitu 0,011<0,050 sehingga Ho ditolak yang berarti secara parsial variabel Perangkat Pendukung berpengaruh signifikan dengan arah yang positif terhadap Implementasi SAP Berbasis Akrual pada Pemerintah Kota Bandung, artinya semakin tinggi atau memadainya Perangkat Pendukung yang ada pada bagian keuangan SKPD Kota Bandung, maka Implementasi SAP Berbasis Akrual pada Pemerintah Kota Bandung pun akan semakin baik. Pengaruh Perangkat Pendukung ini ditunjang pula oleh penjelasan dari hasil pengujian statistik deskriptif dimana rata-rata mayoritas responden sebesar 98 orang memilih setuju dengan skor rata-rata persentase mengenai tanggapan responden tentang Perangkat Pendukung sebesar 68,1\%, yang berarti Perangkat Pendukung yang terdapat di dalam SKPD Kota Bandung berada dalam kategori tinggi atau telah memadai. Sedangkan pada skor rata-rata persentase mengenai tanggapan responden tentang Implementasi SAP Berbasis Akrual pada Pemerintah Kota Bandung sebesar 79,42\% dengan rata-rata mayoritas responden sebesar 98 orang memilih setuju, yang berarti tingkat Implementasi SAP Berbasis Akrual pada Pemerintah Kota Bandung sudah baik. Hasil penelitian ini sejalan dengan hasil penelitian Kristyono et al (2013) yang menyatakan bahwa Perangkat Pendukung yang memadai berpengaruh dan dapat meningkatkan keberhasilan pengelolaan keuangan daerah berdasarkan standar akuntansi pemerintahan.

4.3 Pengaruh Gaya Kepemimpinan terhadap Implementasi Standar Akuntansi Pemerintahan Berbasis Akrual pada Pemerintah Kota Bandung

Berdasarkan hasil pengujian secara parsial seperti yang ditunjukkan pada tabel 2 diperoleh nilai signifikansi Gaya Kepemimpinan yaitu 0,011 >0,050 sehingga Ho diterima yang berarti tidak ada pengaruh. Hal ini dikarenakan Kualitas SDM yang tinggi, sehingga sebaik apapun Gaya Kepemimpinan tidak akan mempengaruhi implementasi SAP bebasis akrual pada Pemerintah Kota Bandung. Oleh karena itu setegas atau sesantai apapun, sebaik apapun Gaya Kepemimpinan seorang pemimpin, dalam hal ini kepala sub bagian keuangan dalam mengatur, menjelaskan, dan memimpin pegawainya, jika pegawai tersebut tersebut telah memiliki tanggung jawab yang tinggi terhadap penyelesaian tugas-tugasnya serta memiliki pemahaman terkait SAP berbasis akrual, maka Gaya Kepemimpinan tidak akan memiliki pengaruh. Hal ini disebabkan pegawai keuangan yang berkualitas tinggi tersebut tetap akan menjalankan seluruh tugastugasnya tanpa diberitahu atau dijelaskan beberapa kali pun oleh pimpinan. Pegawai bagian keuangan juga tetap akan menjalankan tugas-tugasnya, baik ada campur tangan yang besar oleh pimpinan maupun tidak ada.

\section{Kesimpulan dan Saran}

\subsection{Kesimpulan}

Hasil penelitian secara parsial menunjukkan bahwa Kualitas SDM dan Perangkat Pendukung berpengaruh signifikan dengan arah yang positif terhadap Implementasi SAP Berbasis Akrual pada Pemerintah Kota Bandung, namun untuk gaya kepemimpinan tidak berpengaruh terhadap Implementasi SAP Berbasis Akrual pada Pemerintah
JURNAL

MANAJEMEN

INDONESIA

Vol. 17 - No. 1

April 2017 


\section{JURNAL}

MANAJEMEN

INDONESIA

Vol. 17 - No. 1

April 2017
Kota Bandung. Sedangkan secara simultan hasil penelitian menunjukkan bahwa Kualitas SDM, Perangkat Pendukung, dan Gaya Kepemimpinan secara bersama-sama berpengaruh signifikan terhadap Implementasi SAP Berbasis Akrual pada Pemerintah Kota Bandung.

\subsection{Keterbatasan Penelitian}

Saran untuk peneliti selanjutnya, yaitu memperluas sampel penelitian agar mendapatkan hasil yang lebih komprehensif dan gunakan objek penelitian yang berbeda, baik kota/kabupaten maupun provinsi sehingga dapat dijadikan gambaran atau pembanding terkait implementasi SAP berbasis akrual antara satu tempat dengan tempat lainnya tersebut. Selain itu, peneliti selanjutnya dapat menambah variabel lain untuk diuji, seperti sistem pemerintahan dan dukungan konsultan dalam implementasi SAP berbasis akrual. Sedangkan saran bagi Instansi Pemerintah (SKPD Kota Bandung) dalam implementasi SAP berbasis akrual di Kota Bandung diantaranya dengan melaksanakan pelatihan penggunaan perangkat pendukung, terutama software akuntansi yang digunakan untuk implementasi SAP berbasis akrual dan menambah; melakukan pemeliharaan; serta mengganti komputer/hardware pendukung lain yang sudah tidak layak pakai demi menunjang kinerja terkait implementasi SAP berbasis akrual agar menjadi semakin baik.

\section{Daftar Pustaka}

Ardiansyah. 2013. Factors Afffecting The Readiness of PP No. 71 Tahun 2010 about Government Accounting Standards (Case Study on Working Units in KPPN Malang's Working Area). Jurnal Ilmiah Mahasiswa FEB Vol. 1, No. 1.

Arif, M.M. 2013. Analisis Kesiapan Pemerintah Daerah dalam Penerapan Standar Akuntansi Pemerintahan Berbasis Akrual (Studi pada Pemerintah Daerah Kabupaten Bondowoso). Jurnal Akuntansi Universitas Jember Vol. 11, No. 2.

Danim, S. 2010. Kepemimpinan Pendidikan. Alfabeta. Bandung.

Fuad, M.I.Y.K. 2013. Analisis Faktor-faktor yang Mempengaruhi Tingkat Penerapan Akuntansi Akrual pada Pemerintah. Diponegoro Journal of Accounting Vol. 2, No. 3 , pp. 1.

International Public-Sector Accounting Standards Board. 2011. Transition to The Accrual Basis of Accounting: Guidance for Governments and Governments Entities (Third Edition). International Federation of Accountants. New York.

Kristyono, J., Raharjo, K., and Andini, R. 2013. Faktor yang Mempengaruhi Keberhasilan Pelaksanaan Keuangan Daerah sesuai PP 71 / 2010 (Studi pada Dinas Pendidikan Kota Semarang Tahun 2012/2013). Sosio Eko Tekno: Jurnal Ilmiah Mahasiswa Universitas Pandanaran.

Mehrolhassani, M.H., Khayatzadeh-Mahani, K., and Emami, M. 2015. Factors Influencing the Implementation Status of Accrual Accounting System in Health Sector. Global Journal of Health Science; Vol. 7, No. 1.

Negara, I.G.B.S. 2015. Toward Implementation of Accrual Basis in Indonesia Government: Key Success Factors. GSTF Journal on Business Review (GBR) Vol. 4, No. 1.

Nufus, K. 2014. Faktor-faktor yang Mempengaruhi Penerapan Standar Akuntansi Pemerintah pada Pemerintah Kota Baubau. Jurnal Liquidity Vol. 3, No. 1, pp. 11-18.

Nurillah, A.S. 2014. Pengaruh Kompetensi Sumber Daya Manusia, Penerapan Sistem Akuntansi Keuangan Daerah (SAKD), Pemanfaatan Teknologi Informasi, dan Sistem Pengendalian Intern terhadap Kualitas Laporan Keuangan Pemerintah Daerah (Studi Empiris pada SKPD Kota Depok). Skripsi Fakultas Ekonomika dan Bisnis Universitas Diponegoro.

Putra, I.W.G.Y.D. and Ariyanto, D. 2015. Faktor-faktor yang Mempengaruhi Penerapan Standar Akuntansi Pemerintahan Berbasis Akrual. E-Jurnal Akuntansi Universitas Udayana 13.1: 14-32.

$$
\text { Udayana 13.1: 14-32. }
$$


Republik Indonesia. Peraturan Pemerintah No. 24 tahun 2005 tentang Standar Akuntansi Pemerintahan (SAP).

Republik Indonesia. Peraturan Pemerintah No. 71 tahun 2010 tentang Standar Akuntansi Pemerintahan (SAP).

Republik Indonesia. Undang-Undang No. 17 tahun 2003 tentang Pengelolaan Keuangan Negara.

Simanjuntak, B.H. 2010. Penerapan Akuntansi Berbasis Akrual di Sektor Pemerintahan Indonesia. Presented at the Congress XI Institute of Indonesia Chartered Accountants (Ikatan Akuntan Indonesia/IAI). (unpublished)

Sudaryati, D. and Heriningsih, S. 2014. Pengaruh Kompetensi Sumber Daya Manusia terhadap Penerapan Akuntansi Akrual dengan Perangkat Pendukung sebagai Variabel Moderating (Studi Empiris pada Pemerintah Kota Yogyakarta). Jurnal Optimum Vol. 4, No. 2 .

Sukadana, I.C. and Mimba, N.P.S.H. 2015. Pengaruh Kualitas Sumber Daya Manusia terhadap Kesiapan Penerapan SAP Berbasis Akrual pada Satuan Kerja Wilayah Kerja KPPN Denpasar. E-Jurnal Akuntansi Universitas Udayana 12.1: 35-49.

Sulani, A. 2015. Faktor-faktor Pendukung Keberhasilan Penerapan Peraturan Pemerintah No. 24 Tahun 2005 pada Pemerintahan Kabupaten Labuhan Batu. Skripsi Fakultas Ekonomi Universitas Sumatera Utara.

Tjiptono, F. 2011. Pemasaran Jasa. Bayumedia Publishing, Malang. 
JURNAL

MANAJEMEN

INDONESIA

Vol. 17 - No. 1

April 2017 